\title{
Modulation of Crude Oil Induced Alteration of Oxidative Stress Indices in Rat by Red Palm Oil
}

\author{
ACHUBA, FI \\ Department of Biochemistry, Delta State University, PMB 1, Abraka Nigeria. \\ Email:achubabch@yahoo.com
}

\begin{abstract}
The toxic properties of crude oil were hitherto described. Therefore, several materials are being tested for protective potential counter to petroleum toxicity. This study evaluated the oxidative stress status of rats fed diet incorporating petroleum tainted diet with red palm oil. Four groups with six rats in each group were employed in this study. Rats in group 1 were fed with fish feed only while rats in group 2 were fed with crude oil tainted diet and rats in groups 3 and 4 were fed with contaminated feed that was pre-treated with $4 \mathrm{ml}$ and $8 \mathrm{ml}$ of red palm oil respectively. The rats were exposed to the respective diet for 30 days and had water freely. Thereafter standard analytical methods were used to measure oxidative stress markers in organs/tissues of rats. The results showed that crude oil tainted diet stimulated lipid peroxidation and cause decline in reduced glutathione level, superoxide dismutase and catalase activities in the organ/tissues of rats which were significant $(\mathrm{P}<0.05)$ relative to control. Pre-treatment of the rat diets with red palm oil significantly $(\mathrm{P}<0.05)$ drop lipid peroxidation and increase level of antioxidant markers in the organ/tissues of rats in relation to the values in rats fed with diet tainted with crude oil only. This study has confirmed that red palm oil can evade the oxidative insult elicited by crude oil intoxication in various organs/tissues. Therefore, red palm oil should be made a major dietary component for inhabitants of petroleum producing areas of the world.
\end{abstract}

\section{DOI: https://dx.doi.org/10.4314/jasem.v22i6.15}

Copyright: Copyright $(0) 2018$ Achuba. This is an open access article distributed under the Creative Commons Attribution License (CCL), which permits unrestricted use, distribution, and reproduction in any medium, provided the original work is properly cited.

Dates: Received: 09 May 2018; Revised: 28 June: 2018; Accepted: 01 July 2018

Keyword: Antioxidants. Diet, Palm oil, Petroleum

Crude oil is a diverse and harmful chemical that is injurious to the health of exposed animals and man (Ujuwundu et al., 2012; Jing et al., 2016; Dinesh, 2016).The health import of crude oil has been centred on its ability to induce oxidative stress (Achuba et al., 2016), a pathophysiological process that predisposes animals to many diseases (Ezejiofor et al., 2014; Conti and Shaik-Dasthagirisaeb, 2015; Khan et al., 2017) as well as organ and tissue damages (Achuba and Ogwumu, 2014a; Achuba and Nwokogba, 2015). This is the basis why many studies are focussing on search for materials with antioxidant capacity as antidote for crude oil toxicity (Achuba and Nwokogba, 2015; Achuba et al., 2016). A good number of substances with perceived antioxidant properties had been tried against free radical linked damage (George et al., 2012; George et al., 2013; Achuba and Nwokogba, 2015; George et al., 2015; Dinesh, 2016; Okpoghono et al., 2018a). And one such food ingredient that has been tried at histological and biochemical levels is red palm oil (Achuba and Ogwumu, 2014ab). This food ingredient is rich in vitamins and antioxidant (Oguntibeju et al., 2009; Fife, 2010). Moreover, crude oil has been implicated as a free radical generator in exposed animals (Achuba and Osakwe, 2003; Achuba, 2010). The aim of this study was to evaluate the effect of treatment of crude oil contaminated diet with red palm oil on oxidative stress parameters in organs/tissues of wistar albino rats.

\section{MATERIALS AND METHODS}

Materials: Crude oil was obtained from Platform flow Station, Umutu/Ebedei, Delta State, Nigeria. The reagents used are of quality analytical grade.

Experimental animals: Twenty four male albino wistar rats were acquired from a local animal dealer in Abraka. The experimental rats were kept in clean wooden cages and left to acclimatize for two weeks on $1.0 \mathrm{~mm}$ Vita fish feed. Thereafter, the rats were weighed and the weights ranged between 160 to $185 \mathrm{~g}$.

Treatment of animals: The twenty four male wistar albino rats were assigned to four groups with six rats in each group. Rats in control, group 1 were fed with fish feed only. Rats in group 2 were fed with fish feed contaminated with crude oil ( $4 \mathrm{ml}$ per $100 \mathrm{~g}$ of feed). Rats in group 3 were fed with fish feed contaminated with crude oil ( $4 \mathrm{ml}$ per $100 \mathrm{~g}$ of feed) plus $4 \mathrm{ml}$ of red palm oil. Rats in group 4 were fed with fish feed contaminated with crude oil $(4 \mathrm{ml}$ per $100 \mathrm{~g}$ of feed) 
plus $8 \mathrm{ml}$ of red palm oil. The rats in each group were permitted free access to clean drinking water. The quantity of crude oil and red palm oil in the respective diets were established to be tolerated by the animal for a long time in a previous study. The feeds for the groups were prepared fresh daily and left over feed remnants were regularly discarded. The rats were exposed to their respective diets for a period of 30 days.

Preparation of tissue homogenate: The rats were sacrificed after twenty four hours fasting on the 31st day. One gram of each tissue was separately homogenized in $10 \mathrm{ml}$ of normal saline and then centrifuged at 2,500 revolutions per minutes for 15 minutes to obtain the supernatant which was immediately used for biochemical analysis.

Determination of oxidative stress parameters: Oxidative stress parameters were determined in the liver, kidney brain, heart, intestine and testes by using standard methods. Lipid peroxidation was determined by the method of Buege and Aust (1978). The activity of SOD was assayed using the method of Misra and Fridovich (1972). The method reported by Rani et al. (2004) was adopted for the assay of catalase activity. The reduced glutathione concentration was estimated using the method of Ellman (1959).

Statistical Analysis: The data were analyzed using one way analysis of variance (ANOVA) and least significant difference (LSD) using version 20 of SPSS package. Significant differences between groups were set at $\mathrm{P}<0.05$

\section{RESULTS AND DISCUSSION}

Excessive free radical is generated during crude oil toxicity that initiates membrane lipid disintegration (Achuba and Osakwe, 2003; Nwaogu et al., 2011; Ujowundu et al., 2012; Ita and Edagha, 2016). This explains the increase in membrane lipid peroxidation in the tissues of rats fed COD (Table 1). However, treatment of rats fed COD with the different red palm oil significantly decreased the level of lipid peroxidation as compared with that of the control in the respective tissues. This finding corroborates Oyinloye et al. (2016) who reported that aqueous extract of $M$. myristica prevent lipid peroxidation. The reduced lipid peroxidation in the tissues of rats fed COD plus red palm oil indicates the anti-oxidative protective role of red palm oil against COD induced damage on cell membranes. The protective role of red palm oil against petroleum stimulated nephrotoxicity had been reported (Achuba and Ogwumu, 2014a).

The marked reduction in SOD and catalase activities of rats fed COD and the enhanced SOD and catalase activities when red palm oil was administered were in agreement with other studies (Achuba and Otuya, 2006; Sunmonu and Oloyede, 2007; Nwaogu et al., 2011) (Tables 2 and 3). Treatment of COD with red palm oil reversed the activities of antioxidant enzymes: superoxide dismutase and catalase in the organs/tissues of rats. The simultaneous increase in the activities of these enzymes has been reported as a potent defense against petroleum oil stimulated reactive oxygen species (Okpoghono et al., 2018b).

Table 1: MDA levels in organs/tissues of rats fed with red palm oil pretreated crude oil contaminated diet

\begin{tabular}{|c|c|c|c|c|c|c|}
\hline \multicolumn{7}{|c|}{$\mathrm{MDA}$ (nmol/g tissue) } \\
\hline & Liver & Kioney & Brin & Heart & Inteatine & Testes \\
\hline Control & $1.19=0.09^{2}$ & $1.14=0.04^{2}$ & $0.79=0.05^{2}$ & $0.47 \pm 0.04^{2}$ & $1.08=0.04^{2}$ & $0.69=0.05^{2}$ \\
\hline COD & $2.04 \pm 0.20^{\circ}$ & $1.64 \pm 0.08^{\circ}$ & $0.92=0.03^{6}$ & $0.65=0.06^{\circ}$ & $2.23=0.38^{\circ}$ & $0.90=0.11^{\circ}$ \\
\hline COD $+4.0 \mathrm{ml} / 100 \mathrm{gdiet}$ & $1.19=0.12^{2}$ & $1.14 \pm 0.06^{2}$ & $0.79=0.03^{2}$ & $0.43=0.02^{2}$ & $1.21=0.08^{2}$ & $0.65=0.05^{2}$ \\
\hline COD $+8.0 \mathrm{ml} / 100 \mathrm{gdiet}$ & $1.18=0.10^{2}$ & $1.14 \pm 0.07^{2}$ & $0.81=0.04^{2}$ & $0.48=0.05^{2}$ & $1.26=0.10^{2}$ & $0.70=0.06^{2}$ \\
\hline
\end{tabular}

Results are expressed as mean $\pm S D$. Superscript of different letters in a column are significantly $(P<0.05)$ different

Table 2: SOD activities in organs/tissues of rats fed with red palm oil pretreated crude oil contaminated diet

\begin{tabular}{|c|c|c|c|c|c|c|}
\hline \multicolumn{7}{|c|}{ SOD (Unitmg Protein) } \\
\hline & Liver & Kióney & Briin & Heart & Intestine & Teates \\
\hline Control & & & & & & \\
\hline & $40.06=3.08^{4}$ & $29.27=0.87^{4}$ & $19.68 \pm 1.22^{2}$ & $18.48 \pm 0.68^{2}$ & $30.97 \pm 1.10^{2}$ & $19.99=1.32^{2}$ \\
\hline CUD & $18.46=0.68^{\mathrm{b}}$ & $16.52=0.49^{\circ}$ & $18.39 \pm 1.73^{\circ}$ & $14.75=0.44^{\circ}$ & $17.44=0.80^{\circ}$ & $15.89=1.24^{\mathrm{b}}$ \\
\hline 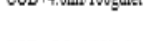 & $30.02=0.91^{2}$ & $26.39=0.57^{2}$ & $18.80 \pm 1.37^{2}$ & $16.53=0.399^{2}$ & $25.97 \pm 1.21^{6}$ & $17.79=0.57^{\circ}$ \\
\hline COD +8.0ml/100gdiet & $30.02=0.89^{2}$ & $27.35=0.48^{2}$ & $18.56 \pm 0.65^{2}$ & $17.12=0.67^{2}$ & $27,42=1.09^{\circ}$ & $18.10=0.66^{2}$ \\
\hline
\end{tabular}

Results are expressed as mean $\pm S D$. Superscript of different letters in a column are significantly $(P<0.05)$ different

In the same vein, addition of red palm oil to the COD reduced the deleterious effect of crude oil by enhancing the level of reduced glutathione in the organs/tissues of rat exposed to the diet (Table 4).
Disruption of antioxidant status by crude oil had been reported (Adedara $e t$ al., 2012; Ebokaiwe and Farombi, 2016).

Similarly, enhancement of reduced glutathione in organ/tissues of rats fed with crude oil contaminated diet by plant derived material with antioxidant property had been reported (Okpoghono et al., 2018b). 
Table 3: Catalase activities in organs/tissues of rats fed with red palm oil pretreated crude oil contaminated diet

\begin{tabular}{|c|c|c|c|c|c|c|}
\hline \multicolumn{7}{|c|}{ Catalase Activity (Unit/mg Protein) } \\
\hline & Liver & Kidiney & Brain & Heart & Intestine & Testes \\
\hline Control & $37.83 \pm 0.83^{\mathrm{a}}$ & $60.68 \pm 1.53^{2}$ & $43.02=0.89^{2}$ & $36.81 \pm 0.69^{2}$ & $38.12=0.40^{2}$ & $43.33 \pm 0.78^{2}$ \\
\hline COD & $20.93 \pm 0.67$ & $31.79 \pm 0.51^{b}$ & $22.53 \pm 0.73^{b}$ & $23.24 \pm 1.15^{b}$ & $30.20 \pm 1.24^{x}$ & $25.69 \pm 1.78^{2}$ \\
\hline $\mathrm{COD}+4.0 \mathrm{ml} / 100 \mathrm{gdiet}$ & $27.85 \pm 0.90^{\circ}$ & $42.36 \pm 2.55^{c}$ & $=29.55 \pm 1.67^{\circ}$ & $27.21 \pm 1.45^{\circ}$ & $33.11 \pm 1.76^{\circ}$ & $34.64=1.66^{\circ}$ \\
\hline $\mathrm{COD}+8.0 \mathrm{ml} / 100$ gdiet & $29.29 \pm 1.09 c$ & $43.97 \pm 2.92^{\circ}$ & $=31.45 \pm 1.90^{\circ}$ & $29.71 \pm 1.08^{c}$ & $33.88 \pm 1.52^{\circ}$ & $35.44=2.21^{2}$ \\
\hline
\end{tabular}

Results are expressed as mean $\pm S D$. Superscript of different letters in a column are significantly $(P<0.05)$ different

Table 4: GSH levels in organs/tissues of rats fed with red palm oil pretreated crude oil contaminated diet

\begin{tabular}{|c|c|c|c|c|c|}
\hline \multicolumn{6}{|c|}{ Reduced Ghtathione (Unitmg Protein) } \\
\hline & Liver & Kidney & Brain & Heart & Intestine \\
\hline Control & $114.59 \pm 1.79$ & $9.49 \pm 1.86^{2}$ & $07.78 \pm 2.09^{2}$ & $113.05 \pm 2.67^{2}$ & $114.95 \pm 1.45^{1} \quad 105.92=1.06^{1}$ \\
\hline $\operatorname{COD} \mid$ & $80.16=0.98^{\circ}$ & $87.86 \pm 0.83^{\circ}$ & $76.19 \pm 1.46^{\circ}$ & $93.65 \pm 0.79$ & $70.29 \pm 0.97^{\circ} 75.64=3.98^{\circ}$ \\
\hline $\mathrm{COD}+4.0 \mathrm{ml} / 100 \mathrm{~g}$ diet & $93.09 \pm 2.73^{\mathrm{c}}$ & $94.89 \pm 5.39^{\circ}$ & $84.59 \pm 3.80^{\circ}$ & $96.52=021$. & $30.95 \pm 1.96^{\circ} \quad 83.47 \pm 0.85^{c}$ \\
\hline $\mathrm{COD}+8.0 \mathrm{ml} / 100 \mathrm{~g}$ diet & $96.92 \pm 4.37^{\circ}$ & $99.08 \pm 5.02 \mathrm{c}$ & $94.05 \pm 3.65^{2}$ & $100.60 \pm 1.95^{2}$ & $102.67 \pm 2.52^{\circ} 39.49 \pm 2.18^{\circ}$ \\
\hline
\end{tabular}

It is no surprise, therefore, that red palm oil pre-treatment of crude oil contaminated diet tend to restore the concentration of reduced glutathione near the values in control animals. This study had been able to establish that red palm oil exhibited positive modulatory effect on crude oil mediated alterations in oxidative stress indices of experimental rats.

\section{REFERENCES}

Achuba, FI; Ogwumu, MD (2014a). Possible protective role of palm oil and beef liver on the kidney and liver of wistar albino rats fed diesel-contaminated diet. Biokemistri: 26 (4) 124-129.

Achuba, FI; Ogwumu, MD (2014b). Effect of palm oil and beef liver on diesel-induced haematotoxicity in wistar albino rats. Biokemistri 26 (4) 120-123

Achuba, FI; Osakwe, SA (2003) Petroleum induced free radical toxicity in Africa catfish (Clarias gariepinus) Fish Physiol. Biochem. 29(2):97-103

Achuba, FI (2010). Spent engine oil mediated oxidative stress in cowpea (Vigna unguiculata) seedlings. EJEAFChem. 9(5): 910-917

Achuba, FI; Nwokogba, CC (2015). Effects of honey supplementation on hydrocarboninduced kidney and liver damage in Wistar albino rats. Biokemistri 27 (1): 50-55.

Achuba, FI; Otuya, EO (2006). Protective influence of vitamins against petroleum induced free radical toxicity in rabbit. Environmentalists, 26 (4): 295-300.

Achuba, FI; Ubogu, LA; Ekute, BO (2016). Moringa oleifera attenuates crude oil contaminated diet induced biochemical effects in wistar albino rats. J Pharma. Biosci. 4 (5):70-77

Adedara, IA; Teberen, R; Ebokaiwe, AP; Ehwerhemuepha, T; Farombi, EO (2012). Induction of oxidative stress in liver and kidney of rats exposed to Nigerian bonny light crude oil. Environ. Toxicol. 27:372-379

Buege, JA; Aust, SD (1978). Microsomal lipid peroxidation. Methods in Enzymol. 52: 302-305
Conti, P; ShaikDasthagirisaeb, Y (2015).

Atherosclerosis: a chronic inflammatory disease mediated by mast cells. Central-Eur $J$. Immunol 40 (3): 380-386.

Dinesh, KG (2016). A Review on processing of crude oil and its production of hydrocarbon intermediates. Indian J. Chem. Technol. 11(6):10511

Ebokaiwe, AP; Farombi, EO (2016). Impact of heavy metals in food products from crude oil polluted area of Nigeria in testicular functions of wistar rats. J. Appl. Life Sci. Inter. 5(2): 1-11

Ellman, GL (1959). Tissue sulfhydryl groups. Arch. Biochem. Biophy. 82:70-77.

Ezejiofor, AN; Orish, E; Orisakwe, $\mathrm{OE}$; Nwigwe, HC; Osuala, FO; Iwuala, MO (2014). Anicteric hepatoxicity: a potential health risk of occupational exposures in Nigerian petroleum oil refining and distribution industry. J. Occup Med Toxicol. 9 (3):1-14 
Fife. B (2007). The Palm Oil Miracle, Piccadilly books, Colorado Springs,USA,.

George, BO, Osioma E, Okpoghono J (2015). Effects of aqueous extract of Xylopia aethiopica and vitamin $\mathrm{E}$ on hepatic and oxidative enzyme markers in rats exposed to cyanide toxicity. Inter J Adv. Res. 3(11):392-397.

George. BO; Osioma, E; Okpoghono, J (2013). Effect of methanolic extract of Aframomum sceptrum on brain lipid profile and non-enzymatic antioxidant level in STZ- induced diabetic rats. Nig. J Nutr. Sci. 34. (1): 13-16.

George, BO; Okpoghono, J; Osioma, E; Aina, OO (2012). Changes in oxidative indices in Plasmodium berghei mice treated with aqueous extract of Aframomum sceptrum. Front. Sci. 2(1): 6-9.

Ita, SO; Edagha, IA (2016). Renal protective effect of antioxidant vitamins $\mathrm{C}$ and $\mathrm{E}$ against crude oil-induced nephrotoxicity. Merit Res. J. Med. Medic. Sci. 4(9):425- 431

Jing, J; Tan, J; Hu, H; Sun, J; Jing P (2016). Rheological and emulsification behaviour of Xinjiang heavy-oil and model oils. Open Fuels Energy Sci. J. 9: $1-10$

Khan, A; Anand, V; Badrinarayanan; V; Thirunethiran, K; Natarajan, P (2017). In vitro antioxidant and cytotoxicity analysis of leave of Ficus racemose. Free Radical Antioxid 7(1): 8-12

Misra, HP; Fridovich, I (1972). The role of superoxide anion in the autooxidation of epinephrine and a sample assay for superoxide dismutase. J. Biol. Chem. 247: 3170-3175.

Nwaogu, LA; Igwe, CU; Ujowundu, CO; Arukwe, U; Ihejirika, CE; Iweke, AV (2011). Biochemical changes in tissues of albino rats following subchronic exposure to crude oil. J. Res. Biol. 8: 617-623

Oguntibeju, O; Esterhuyse, A; Truter, E (2009). Red palm oil: nutritional, physiological and therapeutic roles in improving human wellbeing and quality of life. Br. J. Biomed. Sci. 66:216-222.

Okpoghono, J; Achuba, FI; George, BO (2018). Protective effect of Monodora myristica extracts on crude petroleum oil contaminated catfish (Clarias gariepinus) diet in rats. Int. J. Vet. Sci. Med. https ://doi.org/10.1016/j.ijvsm.2018.03.006

Okpoghono, J; George, BO; Achuba, FI (2018). Assessment of antioxidant indices after incorporating crude oil contaminated catfish and African nutmeg (Monodora myristica) extracts into rat diet. J. Appl Sci. Environ. Manage. 22 (2) $197-202$.

Oyinloye, BE; Adenowo, AF; Osunsanmi, FO, Ogunyinka, BI; Nwozo, SO; Kappo, AP (2016). Aqueous extract of Monodora myristica ameliorates cadmium-induced hepatotoxicity in male rats. Springerplus 5: 641-648 